\title{
HIDDEN DANGEROUS GOODS CONTAINING LITHIUM BATTERIES SHIPMENT BY AIR FREIGHT
}

\author{
M. Rifni ${ }^{1}$, Luthfiani Rachmatia Agustin ${ }^{2}$, Nada Septiara ${ }^{3}$ \\ 1. STMT Trisakti, 2. STMT Trisakti, 3. STMT Trisakti \\ corresponding author : nadaseptiara22@gmail.com
}

\begin{abstract}
Lithium batteries recently become recommended power sources due to its advantages which have high specific energy, high capacity, long cycle, etc. The development of lithium batteries pushes the development and production of electonic equipments to the next step. As the effect, the demand for electronic equipment shipments rises. Besides creating opportunities, lithium batteries also pose threats due to its capability of posing hazards which endanger flight safety. In air transport history, there are many accidents occured due to lithium batteries carriages. One of the factors that induces lithium battery deficiency is mishandling due to inaccurate information about the goods. A lot of goods that may contain lithium battery such as electronic equipment, medical equipment, machinery parts, etc. often declared as general cargo by the shipper. To prevent and minimize accident caused by hidden dangerous goods, air carrier staffs are demanded to comprehend informations related to dangerous goods. This paper explains a glimpse of information about hidden dangerous goods containing lithium batteries shipment by air freight.
\end{abstract}

Keywords : Lithium batteries, air cargo, hidden, dangerous goods, safety.

\section{Introduction}

52 million metric tons of goods have been transtported by aircraft in 2016, which is 0.5 million metrics tons higher than in 2015 (IATA, 2017b). The growth in air cargo demand shows potential in the growth of dangerous goods air freight demand. The term dangerous goods refers to all goods and materials which capable of posing risks to health, safety, property and evironment (IATA, 2017a). Due to its adequacy in posing hazards, dangerous good classified as special cargo which shipment needs special handling and is strictly regulated. In air freight industry, the fundamental regulations for shipping dangerous goods established by International Civil Aviation Organization (ICAO) and International Air Transport Association (IATA). Each countries might have different organizations and regulations regarding dangerous goods shipment, but they still refer to ICAO and IATA (IATA, 2017a).

Eventhough dangerous goods shipments are strictly regulated, there are times when dangerous goods is not declared as it is. It is called hidden or 
undeclared dangerous goods. As an illustration, a shipper books an air freight service to transport machinery parts which declared as a general cargo. IATA DGR clarifies that machinery parts in some cases may contain adhesives, lithium batteries, and other hazardous materials. Therefore all human resources involved in hazardous cargo transport process should ferret out confirmation from the shipper that the package does not contain any hazardous materials.

Another material which often found undeclared is lithium battery. Lithium batteries has been getting plenty attentions since the prohibition of carrying Samsung Galaxy Note 7 into aircraft by several airlines due to the batteries that overheated and exploded (Gibbs, 2016). The hazards of lithium batteries are obviously able to endanger flight safety. The hazards will be more threathening when lithium batteries contained in equipment carried as an undeclared or hidden dangerous goods, as it will be mishandled.

In order to minimize the incidents and accidents in aircraft caused by lithium battery carriage, lithium batteries shipments are firmly regulated. And also, dangerous goods training and education are obligatory for everyone that involved in transporting dangerous goods (Ministry of Transportation of Republic of Indonesia, 2015).

\section{Method}

This research used descriptive method. According to Whitney descriptive method is the search for facts with appropriate interpretation. Descriptive research studies the problems in society and the prevailing procedures in society and in particular situations (Nazir, 2003).

According to Nazir descriptive method is a method in examining the status of a group of people, an object, a conditions, a system of thought or a class of events in the present. The purpose of this descriptive study is to create a description, describe systematically, factual and accurate about facts, traits and relationships between phenomena that investigated (Nazir, 2003). 
From theories above we can conclude that descriptive method is a research method that requires the researcher to describe the facts about a problem more specifically, detailed and accurate. The aim of this method is to explain a study in accordance with the actual occurrence or without manipulation.

The type of the research was using qualitative research because the data analysis in the form of words written or spoken and considered the opinions of others who can be called the resource (Nazir, 2003).

Using descriptive method in the research about hidden dangerous good especially lithium batteries, we can explain specifically about what is hidden dangerous goods and lithium batteries, what kind of lithium batteries, safe procedure in handling lithium batteries and requirements that must be done by an airline staff to minimize the incident or accident resulting from the handling of hidden dangerous good.

In this research, descriptive method was supported by secondary data that is data information related to the problem of research where data are obtained from books, internet, and related documents.

\section{Discussion and Result}

\section{Hidden Dangeorus Goods}

The basic regulation of transporting dangerous goods by air is Annex 18 to the Chicago Convention and the associated Technical Instructions for the Safe Transport of Dangerous Goods by Air published by ICAO. Another well-known regulation was also published by IATA, IATA Dangerous Goods Regulations which actually based on Annex 18 to the Chicago Convention and regularly updated.

Dangerous goods are divided into 9 classes based on the harzard contained, which are explosives, gases, flammable liquids, flammable solids, oxidizing substances and organic peroxides, toxic and infectious substances, radioactive materials, corrosives and miscellaneous dangerous goods (Hsu, Huang, \& Tseng, 2016). Some of the hazard classes are also divided into hazard divisions due to the broad scope of the class. In 
accordance with the various class of hazard, dangerous goods are also divided into 3 packaging groups based on its danger level. Packing Group I for the goods with high danger, Packing Group II for goods with medium danger, and Packing Group III for goods with low danger (Bender \& Eisenbarth, 2013).

Hidden or undeclared dangerous good refer to the dangerous good which is declared as a non hazardous by the shipper and the dangerous good which already declared as hazardous material yet has innacurate description, for example, when the quantity stated by shipper is lower than the actual weight so the staff lifted the goods on passenger aircraft even though it should be on cargo aircraft only (GAO, 2003).

An improper identification about the goods may lead to further mistake such as inappropriate packaging, mishandling, etc. and these mistakes are capable to bring catastrophic consequences during the process of storage, handling and transporting dangerous goods. There are a lot of accidents occured, due to cargo mishandling (Kania, 2016). One of the incident caused by improper goods identification occured in 2015. A package inside a unit load device being loaded into a cargo aircraft was burning in the middle of loading process in Oregon. This package contained undeclared lithium ion batteries having no dangerous goods markings, labels or other indicators revealing the dangerous nature of the cargo (FAA Office of Security and Hazardous Materials Safety, 2017).

\section{Lithium Batteries}

For regulation purposes, lithium batteries are divided into lithium metal batteries and lithium-ion batteries that includes lithium polymer batteries. Lithium metal batteries are not rechargeable and they have lithium metal or lithium compounds as an anode. Lithium-ion batteries are recharegable and have been considered as a safer choice to lithium metal batteries (Lisbona \& Snee, 2011). The two lithium batteries are classified in the Class 9 of hazard classes. The safety matters created by lithium metal battery including the generation of highly flammable hydogen gas that tipically followed by ignition due to the contact of lithium metal with water, 
thermal runaway, and oxidation of organic solvents by lithium perchlorate (which is a strong oxidising agents known to give rise to explosive reactions with organic substances) (Lisbona \& Snee, 2011). Lithium-ion battery can form molten lithium when overly charged and a thermal runaway might as well happen (Lisbona \& Snee, 2011). Once lithium batteries ignited, the batteries surrounding will overheat and explode. The fire will be difficult to estinguish and produces irritating fumes (Transport Canada, 2015). The hazards of lithium batteries can harm both things and people surrounding.

In spite of the hazards, some of lithium batteries can be carried by aircraft. Lithium ion batteries shipment in passenger aircraft as a cargo was permitted until the 36-State ICAO Governing Council adopted a regulation which effective since April 2016 (ICAO, 2016). So from then and now, shipment of lithium ion and lithium metal batteries as cargos can only be carried by cargo aircraft. The regulation does not applied for those contained in personal electronic devices carried by passengers or crew.

Hidden Dangerous Goods Containing Lithium Batteries

There are several goods that likely to be hidden dangerous goods that may contain lithium battery such as medical equipments, electronic equipments, cameras, machinery parts, etc. Cargo reservation staffs should check the correct commodity and ensure no hazardous goods included before confirming any booking when shipper wants to transport one of the goods that likely to have lithium batteries installed. This practice may diminish the probability to have an undeclared dangerous goods on board.

As a hidden dangerous good, lithium battery usually found to be packed with the equipment or contained in it. Lithium battery packed with the equipment means the battery is located inside the package but not installed to the equipment, while lithium battery contained in equipment means the battery is installed in it. When a lithium battery found to be packed or contained in equipment, cargo staffs should seek confirmation that the batteries have passed the UN Manual Tests and Criteria Part III Subsection 38.3 and is not defected nor damaged (IATA, 2017a). The 
following table will show in which aircraft lithium batteries can be carried as cargo according to IATA DGR 58th edition.

Table 1

\begin{tabular}{|l|c|c|c|}
\hline & Limited Qty & $\begin{array}{c}\text { Passenger and } \\
\text { Cargo Aircraft }\end{array}$ & $\begin{array}{c}\text { Cargo Aircraft } \\
\text { Only }\end{array}$ \\
\hline Lithium ion batteries & NO & NO & YES \\
\hline $\begin{array}{l}\text { Lithium ion batteries packed with } \\
\text { equipment }\end{array}$ & NO & YES & YES \\
\hline $\begin{array}{l}\text { Lithium ion batteries contained in } \\
\text { equipment }\end{array}$ & NO & YES & YES \\
\hline Lithium metal batteries & NO & NO & YES \\
\hline $\begin{array}{l}\text { Lithium metal batteries packed } \\
\text { with equipment }\end{array}$ & NO & NO & YES \\
\hline $\begin{array}{l}\text { Lithium metal batteries contained } \\
\text { in equipment }\end{array}$ & NO & YES \\
\hline
\end{tabular}

In table 1 , the term limited quantities refers to the provision for several dangerous goods that when carried in a reasonably limited quantities have reduced hazard, so it can be carried safely in good quality packagings of the types specified in UN recommendations but which have not been tested and marked accordingly (IATA, 2017a). IATA has forbid the carriage of lithium batteries in limited quantities, which means all lithium batteries shipments should be tested and marked. Tables 2 and 3 aimed to provide information about the conditions of lithium batteries both packed with equipment and contained in equipment which can be accepted in the aircraft.

Table 2

\begin{tabular}{|c|c|c|c|}
\hline \multicolumn{4}{|c|}{ LITHIUM ION BATTERIES } \\
\hline \multicolumn{2}{|c|}{ PACKED WITH EQUIPMENT } & \multicolumn{2}{|c|}{ CONTAINED IN EQUIPMENT } \\
\hline UN 3481 & UN 3481 & UN 3481 & UN 3481 \\
\hline PI 966 & PI 966 & PI 967 & PI 967 \\
\hline SECTION I & SECTION II & SECTION I & SECTION II \\
\hline $\begin{array}{l}\text { - } \text { Batteries }>100 \mathrm{Wh} \\
\text { - Limit Per Package : } \\
\text { pax aircraft }=5 \mathrm{~kg} \\
\text { cargo aircraft = } \\
35 \mathrm{~kg} \\
\text { - IMP : RLI } \\
\text { - Description of } \\
\text { content in AWB :- }\end{array}$ & $\begin{array}{l}\text { - Batteries } \leq 100 \mathrm{Wh} \\
\text { - Limit Per Package : } \\
\text { pax aircraft = } 5 \mathrm{~kg} \\
\text { cargo aircraft = 5 kg } \\
\text { - IMP : ELI } \\
\text { - Description of } \\
\text { content in AWB : } \\
\text { "Lithium ion } \\
\text { batteries in } \\
\text { compliance with } \\
\text { Section II of PI } \\
\text { 966" }\end{array}$ & $\begin{array}{l}\text { - Batteries > } 100 \mathrm{Wh} \\
\text { - Limit Per Package : } \\
\text { pax aircraft = 5kg } \\
\text { cargo aircraft = } \\
\text { 35kg } \\
\text { - IMP : RLI } \\
\text { - Description of } \\
\text { content in AWB : - }\end{array}$ & $\begin{array}{l}\text { - Batteries } \leq 100 \mathrm{Wh} \\
\text { - Limit Per Package : } \\
\text { pax aircraft = 5 kg } \\
\text { cargo aircraft = } 5 \mathrm{~kg} \\
\text { - IMP : ELI* } \\
\text { - Description of } \\
\text { content in AWB : } \\
\text { "Lithium ion } \\
\text { batteries in } \\
\text { compliance with } \\
\text { Section II of PI } \\
\text { 967" }\end{array}$ \\
\hline
\end{tabular}


Table 3

\begin{tabular}{|c|c|c|c|}
\hline \multicolumn{4}{|c|}{ LITHIUM METAL BATTERIES } \\
\hline \multicolumn{2}{|c|}{ PACKED WITH EQUIPMENT } & \multicolumn{2}{|c|}{ CONTAINED IN EQUIPMENT } \\
\hline UN 3091 & UN 3091 & UN 3091 & UN 3091 \\
\hline PI 969 & PI 969 & PI 970 & PI 970 \\
\hline SECTION I & SECTION I & SECTION I & SECTION II \\
\hline $\begin{array}{l}\text { - Batteries }>2 \mathrm{~g} \\
\text { - Limit Per Package : } \\
\text { pax aircraft = 5kg } \\
\text { cargo aircraft = } \\
\text { 35kg } \\
\text { - IMP : RLM } \\
\text { - Description of } \\
\text { content in AWB : - }\end{array}$ & $\begin{array}{l}\text { - Batteries } \leq 2 \mathrm{~g} \\
\text { - Limit Per Package : } \\
\text { pax aircraft = } 5 \mathrm{~kg} \\
\text { cargo aircraft = } 5 \mathrm{~kg} \\
\text { - IMP : ELM } \\
\text { - Description of } \\
\text { content in AWB : } \\
\text { "Lithium metal } \\
\text { batteries in } \\
\text { compliance with } \\
\text { Section II of PI } \\
969 "\end{array}$ & $\begin{array}{l}\text { - Batteries }>2 \mathrm{~g} \\
\text { - Limit Per Package : } \\
\text { pax aircraft = 5kg } \\
\text { cargo aircraft = } \\
\text { 35kg } \\
\text { - IMP : RLM } \\
\text { - Description of } \\
\text { content in AWB : - }\end{array}$ & $\begin{array}{l}\text { - Batteries } \leq 2 \mathrm{~g} \\
\text { - Limit Per Package : } \\
\text { pax aircraft }=5 \mathrm{~kg} \\
\text { cargo aircraft }=5 \mathrm{~kg} \\
\text { - IMP : ELM* } \\
\text { - Description of } \\
\text { content in AWB : } \\
\text { "Lithium metal } \\
\text { batteries in } \\
\text { compliance with } \\
\text { Section II of PI } \\
\text { 970" }\end{array}$ \\
\hline
\end{tabular}

* Marking requirement exception for shipments of two packages or less where each package contains no more than two batteries fitted in equipment

For handling purpose, dangerous goods packages should have marks and labels which show their hazardous nature of the cargo. For cargo containing lithium batteries, lithium battery label should be printed or sticked on the outer packaging. For cargo which IMP codes are RLI and RLM, the label (figure 1) must shown properly without being folded. For those which IMP codes are ELI and ELM, figure 2 should be shown in the outer package as the label.

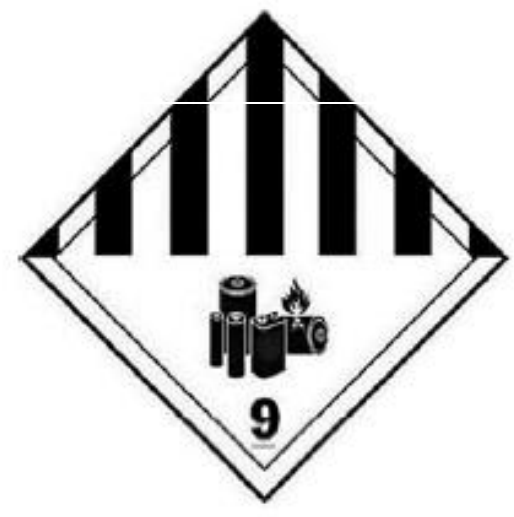

Figure 1

Source : IATA

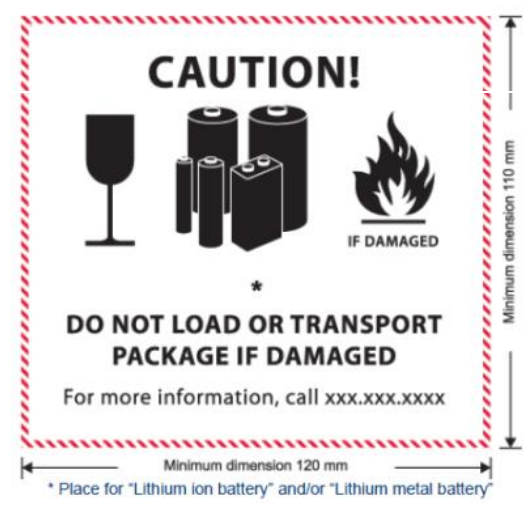

Figure 2

Source : IATA

After thoroughly inspect the batteries, cargo staffs should make a decision.

If the battery contained in or packed with the equipment meets the 
requirements, carrier may uplift the goods after shipper revise the document and the package. The cargo must be correctly packed, marked and labelled, properly declared, ensure no-short circuit, and have complete documents. Each package also should capable withstanding a $1.2 \mathrm{~m}$ drop test in any orientation without breakage to batteries contained, shifting of the contents so as to make battery to battery contact, and release of contents (IATA, 2017a). If the cargo does not fulfill the requirements, cargo staffs have the right to object the cargo or ask the shipper to uninstall the battery contained in the equipment within the time that has been determined by carrier staffs so that it can be accepted without causing delay.

If an undeclared lithium battery causing an incident where fire, explosion, or heat sufficient to be dangerous to packaging or personal safety, the local emergency services should take control of the package. The station engineer and pilot in command must be informed directly upon the incident. If necessary, passengers and staffs will be evacuated. The packages must be safely remove from unit load device or aircraft. And the incident must be reported accordingly.

It indeed needs significant cooperation of all parties involved to move lithium batteries safely. In air cargo industry, shipper plays a big role as the demand generator (Ricardianto \& Rifni, 2014). Thus, they need to be more accurate in declaring and packing the goods when they want to book a shipment containing hazardous materials to minimize improper goods description. Cargo carrier staffs should be more conscientious when making a reservation, handling and transporting cargo containing lithium batteries. Air carrier should focus on fulfilling the needs and wants of consumers with fast and accurate service (Umagapi et al., 2016). The adjustment of lithium batteries shipment regulation and standard operating procedure should be well-informed to all parties involved in transporting lithium batteries. Lithium batteries shipments have to be under a strict supervision to minimize the probability of mishandling and acccidents. 


\section{Conclusion}

Lithium batteries divided into lithium ion batteries and lithium metal batteries. Lithium batteries carriage by aircraft is not fully prohibited. Lithium batteries which meet the requirements stated in IATA DGR, carrier provisions and state regulations may be uplifted into aircraft. Lithium batteries often found undeclared as it is packed with equipment or installed in equipment. All parties involved in dangerous goods shipment required to be meticulous to prevent any undeclared dangerous goods. When an undeclared lithium battery obtained, cargo staffs should precisely take decision regarding the cargo. The decision indeed should based on whether the lithium battery meet the requirements or not. If it does not meet the requirement, the staff should call the shipper immediately upon the rejection of cargo or the conditions shipper have to fulfill so that the cargo could be accepted. When an incident caused by lithium batteries happened, an emergercy response should be conveyed. The incident must be inspected and reported accordingly.

\section{References}

Bender, H. F., \& Eisenbarth, P. (2013). Hazardous Chemicals : Control and Regulation in the European Market.

FAA Office of Security and Hazardous Materials Safety. (2017). LITHIUM BATTERIES \& LITHIUM BATTERY-POWERED DEVICES. Retrieved from https://www.faa.gov/about/office_org/headquarters_offices/ash/ash_pr ograms/hazmat/aircarrier_info/media/battery_incident_chart.pdf

GAO. (2003). Undeclared Air Shipments of Dangerous Goods and DOT' s Enforcement Approach. United States Government Accountability Office, (January), 1-42.

Gibbs, S. (2016). Samsung Galaxy Note 7: airlines across Asia, the US and Europe ban exploding smartphone. Retrieved from https://www.theguardian.com/technology/2016/oct/17/samsunggalaxy-note-7-airlines-asia-us-europe-ban-exploding-smartphone

Hsu, W. K. K., Huang, S. H. S., \& Tseng, W. J. (2016). Evaluating the risk of operational safety for dangerous goods in airfreights - A revised risk matrix based on fuzzy AHP. Transportation Research Part D: Transport and Environment, 48, 235-247. https://doi.org/10.1016/j.trd.2016.08.018

IATA. (2017a). Dangerous Goods Regulation (58th ed.). 
IATA. (2017b). The Value of Air Cargo. Retrieved from http://www.iata.org/whatwedo/cargo/pages/index.aspx

ICAO. (2016). ICAO Council Prohibits Lithium-Ion Cargo Shipments on Passenger Aircraft. Retrieved November 12, 2017, from https://www.icao.int/Newsroom/Pages/ICAO-Council-ProhibitsLithium-Ion-Cargo-Shipments-on-Passenger-Aircraft.aspx

Kania, D. D. (2016). Analisis Faktor Budaya Keselamatan dan Kesehatan Kerja ( K3 ) Pada Penanganan Kargo Di Bandara Soekarno Hatta International Airport. Jurnal ManajemenTransportasi \& Logistik, 3(1), $1-13$.

Lisbona, D., \& Snee, T. (2011). A review of hazards associated with primary lithium and lithium-ion batteries. Process Safety and Environmental Protection, 89(6), 434-442. https://doi.org/10.1016/j.psep.2011.06.022

Ministry of Transportation of Republic of Indonesia. (2015). Peraturan Direktur Jenderal Perhubungan Udara No : KP 546 Tahun 2015.

Nazir, M. (2003). Metodologi Penelitian.

Ricardianto, R. P., \& Rifni, M. (2014). Air Cargo Capacity on Cargo Terminal Development Plan at Soekarno-Hatta International Airport. Jurnal ManajemenTransportasi \& Logistik, 1(2).

Transport Canada. (2015). Did you know that Lithium Batteries are Dangerous Goods. Retrieved from https://www.tc.gc.ca/eng/tdg/lithium-batteries-are-dangerous-goods1162.html

Umagapi, B. W., Manajemen, S. T., Trisakti, T., Amonalisa, S., Manajemen, S. T., Trisakti, T., ... Trisakti, T. (2016). Bongkar Muat General Cargo the Documents Service Quality and the Speed. Jurnal ManajemenTransportasi \& Logistik, 3(3), 379-386. 